\title{
Socio-Economic Personal Antecedents of Dairy Farmers of Jaipur District of Rajasthan, India
}

\author{
Rahul Choudhary ${ }^{1 *}$, Rohitash Kumar ${ }^{2}$ and Vinay Kumar ${ }^{2}$ \\ ${ }^{1}$ Department of Veterinary \& Animal Husbandry Extension Education, Mahatma Jyotiba Fule \\ College of Veterinary \& Animal Science, Chomu-303702 (Rajasthan), India \\ ${ }^{2}$ Department of Veterinary \& Animal Husbandry Extension Education, CVAS, Navania, \\ Vallabhnagar, Udaipur (Rajasthan)-313601, India \\ *Corresponding author
}

\section{A B S T R A C T}

\begin{tabular}{|l|}
\hline K e y w or d s \\
$\begin{array}{l}\text { Personal } \\
\text { antecedents, Dairy } \\
\text { farmers }\end{array}$ \\
\hline Article Info \\
\hline $\begin{array}{l}\text { Accepted: } \\
\text { 24 August } 2018 \\
\text { Available Online: } \\
\text { 10 September } 2018\end{array}$ \\
\hline
\end{tabular}

\section{Introduction}

India is predominantly an agrarian society where animal husbandry plays an important role in the socio economic development of India. India's livestock sector is one of the largest sectors in the world. India's livestock sector is one of the largest in the world with a holding of $11.6 \%$ of world livestock population which consist buffaloes $(57.83 \%)$, cattle (15.06\%), sheep (7.14\%) and goats 17.93 per cent (Anonymous, 2014). As per $19^{\text {th }}$ livestock census, Rajasthan state has 6.98 ,
The present study was conducted to ascertain the socio economic personal antecedents of the dairy farmers of Jaipur district of Rajasthan. There are total thirteen tehsils in Jaipur district, out of which four tehsils Viratnagar, Shahpura, Chmou and Phulera were randomly selected. Five villages from each tehsil were also randomly selected. For selection of respondent's twelve farmers who possess at least 5 milch (dairy) animals either cattle or buffalo and both practicing dairy farming were selected randomly from each village as respondents for the study. Thus, total 120 dairy farmers were selected. The study revealed that majority of the respondents was having middle age group, Middle level of education, medium family size and medium dairy experience. It can also observed that majority of the respondents had not attended any training related to dairy management practices. Majority of the respondent were having medium level of economic motivation, extension contact and mass media exposure. It suggested that there is a need for conducting need based training programmes by the extension agencies in the study area. 
food security and insurance against poverty. Development of livestock sector has a significant beneficial impact in generating employment and reducing poverty in rural India. A clear understanding of the personal socio economic profile of the dairy farmers is of paramount importance in designing need based and farmer centered extension programmes. With this background the present study was conducted to know the personal antecedent characteristics of dairy farmers of Jaipur district of Rajasthan.

\section{Materials and Methods}

The study was conducted in Jaipur district of Rajasthan state selected purposely keeping in view the fact that the district has highest population of livestock. Jaipur district has about 28.03lacs livestock population $\left(19^{\text {th }}\right.$ livestock census Rajasthan-2012). Out of thirteen tehsils four tehsils i.e. Viratnagar, Shahpura, Chmou and Phulera were randomly selected for the study. Five villages were then random sampling technique.

Thus, a total of twenty villages were selected in all. Twelve farmers who possess at least 5 milch (dairy) animals either cattle or buffalo and both practicing dairy farming were selected randomly from each village as respondents for the study. Therefore, the total sample size for this study was 120 dairy farmers.

The data were collected with the help of pretested structured interview schedule by holding personal interview with dairy farmers by the researcher.

\section{Results and Discussion}

The results of socio-economic personal antecedents of dairy farmers were depicted in the Table 1 showing the socio-economic profile of the dairy farmers.
Age

Results in Table 1 show that majority of the dairy farmers belonged to the middle age group $(67.50 \%)$, and 20.83 per cent farmers have old age group. Remaining 11.67 per cent farmers have young age. These results indicate that middle aged farmers taking up dairying as income generating activity as they are more capable physically and could shoulder more family responsibilities. Almost similar findings were observed by Raval and Chandawat (2011) and Chandrasekar et al., (2017) who found that majority of the respondents belongs to medium age group.

\section{Education}

The data indicate that majority 67.50 per cent dairy farmers were having middle level of education. 15.83 per cent and 9.17 per cent respondents having primary and secondary and above level of education in the study area. Only a few 7.50 per cent respondents were illiterate. The probable reason behind this might be that the facility for primary to higher secondary education available at village or nearby areas. The fact revealed that the livestock farmers started schooling tried to reach at least higher secondary level before he has drop out. Almost similar findings were observed by Jaiswal et al., (2013) who found that majority of the respondents had middle level of education.

\section{Family size}

It was noticed that 52.50 per cent of the respondents belonged to medium category followed by small 39.16 per cent and rest of them 8.34 per cent of respondents were having large category of family size. This implies that the farmers were aware of the advantages of family planning. The findings are in line with the findings of Bhosale et al., (2014) and Raina et al., (2016) who found that majority of 
the respondents were having medium size families.

\section{Experience in dairying}

The data depicted in Table 1 shows that majority of the respondents 69.16 per cent had medium level of dairying experience while 19.18 per cent of them were have high and rest of them 11.67 per cent respondents had low dairying experience that indicates the venturing of dairy farming by average experienced farmers is encouraging. However, it is to be noted that dairy sector requires sustained interest and continuous efforts by farmers for long time. The findings are in line with the findings of Roy et al., (2013) who found that majority of the respondents were having medium experience of dairy farming.

\section{Training's attended}

It is evident from the data accommodated in table 1 that 87.5 per cent respondents had not attended any training while 12.5 per cent respondents had attended different types of training related to dairy practices.

Unawareness among farmers for training institutions and the training schedules leads to less number of trainees in these programmes. Therefore, it is suggested that the extension agencies, voluntary organizations and dairy cooperative societies should undertake training activity on a regular basis after properly assessing the training needs of dairy farmers. The findings are in line with the findings of Godara (2017) who found that majority of the respondents never attended any type of training related to dairy farming.

\section{Social participation}

Overall analysis of Table 1 indicates that majority $(67.50 \%)$ of dairy farmers having no social participation. $17.50,14.17$ and 10.83 per cent of dairy farmers had medium, high and low level of social participation in the study area. The poor participation in social organizations may be due to the unawareness and lack of interests on the part of respondents to become the member might have committed them to devote more time in earning their living resulting into very little time left for participation in social organization.

\section{Land holding}

The data indicated in Table 1 depict that among the dairy farmers, 44.17 per cent of the respondents have small land holding followed by medium $(25.83 \%)$ land holdings and 22.50 per cent of them were landless. Remaining 7.50 per cent of them was large land holding.

The reason for possession of small land holding by majority of respondents could be due to subdivision and fragmentation of land because of breaking down of joint families in to nuclear ones. The findings are in line with the findings of Sarita et al., (2016) who found that majority of the respondents have small size of land holding.

\section{Occupation}

Overall analysis of Table 1 indicates that majority $(65.83 \%)$ of dairy farmers had dairying + agriculture occupation. 21.67 and 12.50 per cent of dairy farmers having dairying and agriculture + others and dairying occupation respectively in the study area. This may be due to the continuation of ancestral traditional occupation of agriculture along with livestock rearing by majority of farmers in the study area.

The findings are in line with the findings of Bhosale et al., (2014) and Raina et al., (2016) who found that majority of the respondents, belongs to dairy and agriculture category of occupation. 
Table.1 Distribution of the respondents according to various antecedent characteristics

\begin{tabular}{|c|c|c|c|c|c|}
\hline \multirow[t]{2}{*}{ S. No. } & \multirow{2}{*}{$\begin{array}{l}\text { Antecedent } \\
\text { characteristics }\end{array}$} & \multirow[t]{2}{*}{ Mean \& SD } & \multirow[t]{2}{*}{ Category } & \multicolumn{2}{|c|}{ Dairy Farmers } \\
\hline & & & & $\mathbf{F}$ & $\mathbf{P}$ \\
\hline \multirow[t]{3}{*}{1.} & \multirow[t]{3}{*}{ Age } & \multirow{3}{*}{$\begin{array}{c}\text { Mean }=49.17 \\
\mathrm{SD}=9.72\end{array}$} & Young (below 34 years) & 14 & 11.67 \\
\hline & & & Middle (35-58 years) & 81 & 67.50 \\
\hline & & & Old (above 58 years) & 25 & 20.83 \\
\hline \multirow[t]{4}{*}{2.} & \multirow[t]{4}{*}{ Education } & \multirow{4}{*}{$\begin{array}{c}\text { Mean }=2.40 \\
\mathrm{SD}=1.06\end{array}$} & Illiterate $(0)$ & 9 & 7.50 \\
\hline & & & Primary(1) & 19 & 15.83 \\
\hline & & & Middle(2) & 81 & 67.50 \\
\hline & & & Secondary and above(3) & 11 & 9.17 \\
\hline \multirow[t]{3}{*}{3.} & \multirow[t]{3}{*}{ Family Size } & \multirow{3}{*}{$\begin{array}{c}\text { Mean }=1.61 \\
\mathrm{SD}=0.72\end{array}$} & Small (up to 4 members) & 47 & 39.16 \\
\hline & & & Medium (5-7 members) & 63 & 52.50 \\
\hline & & & Large (>7 members) & 10 & 8.34 \\
\hline \multirow[t]{3}{*}{4.} & \multirow{3}{*}{$\begin{array}{l}\text { Experience } \\
\text { dairying }\end{array}$} & \multirow{3}{*}{$\begin{array}{c}\text { Mean }=33.40 \\
\mathrm{SD}=5.13\end{array}$} & Low (up to 27 years) & 14 & 11.67 \\
\hline & & & Medium (27-39 years) & 83 & 69.15 \\
\hline & & & High (above 39years) & 23 & 19.18 \\
\hline \multirow[t]{2}{*}{5.} & \multirow{2}{*}{$\begin{array}{l}\text { Training's } \\
\text { attended }\end{array}$} & \multirow{2}{*}{$\begin{array}{c}\text { Mean }=0.35 \\
\mathrm{SD}=0.47\end{array}$} & Yes(1) & 42 & 35.00 \\
\hline & & & $\mathrm{No}(0)$ & 78 & 65.00 \\
\hline \multirow[t]{4}{*}{6.} & \multirow{4}{*}{$\begin{array}{l}\text { Social } \\
\text { participation }\end{array}$} & \multirow{4}{*}{$\begin{array}{c}\text { Mean }=0.58 \\
\mathrm{SD}=0.92\end{array}$} & No Participation (0) & 81 & 67.50 \\
\hline & & & Low (1) & 13 & 10.83 \\
\hline & & & Medium(2) & 21 & 17.50 \\
\hline & & & $\operatorname{High}(3)$ & 5 & 4.17 \\
\hline 7. & Land holding & Mean=1.18 & Landless & 27 & 22.50 \\
\hline & & $\mathrm{SD}=0.87$ & Small (up to 5 acre) & 53 & 44.17 \\
\hline & & & Medium (5.01 to 10 acre) & 31 & 25.83 \\
\hline & & & Large (more than 10 acre) & 9 & 7.50 \\
\hline 8. & Occupation & Mean=2.09 & Dairy farming & 15 & 12.50 \\
\hline & & $\mathrm{SD}=0.58$ & Dairy farming + Agriculture & 79 & 65.83 \\
\hline & & & $\begin{array}{l}\text { Dairy farming }+ \text { Agriculture }+ \\
\text { Others }\end{array}$ & 26 & 21.67 \\
\hline 9. & Herd size & Mean $=10.65$ & Small (up to 7animals) & 19 & 15.83 \\
\hline & & $\mathrm{SD}=8.23$ & Medium (8-19 animals) & 95 & 79.17 \\
\hline & & & Large (>19 animals) & 9 & 7.50 \\
\hline 10. & Economic & Mean $=7.6$ & Low (below 7) & 25 & 20.83 \\
\hline & Motivation & $\mathrm{SD}=1.04$ & Medium (7-9) & 74 & 61.67 \\
\hline & & & High (above 9) & 21 & 17.50 \\
\hline 11. & Extension & Mean=6.01 & Low (up to 4) & 27 & 22.50 \\
\hline & contact & $\mathrm{SD}=1.91$ & Medium (5-7) & 67 & 55.83 \\
\hline & & & High (above 7) & 26 & 21.67 \\
\hline 12. & Mass media & Mean $=8.3$ & Low (up to 8) & 28 & 23.33 \\
\hline & exposure & $\mathrm{SD}=1.34$ & Medium (9-10) & 88 & 73.34 \\
\hline & & & High (above10) & 4 & 3.33 \\
\hline
\end{tabular}




\section{Herd size}

The data represent that majority 79.17 per cent of the respondents were having medium herd size followed by 15.83 and 7.50 per cent of respondents were having large and small herd size respectively. It was observed that the dairy farmers possessed mostly local breeds of the animals with low production potential. It is therefore suggested that they should own improved breeds of dairy animals for more profitable and productive dairy units. The findings are in line with the findings of Roy et al., (2013) who found that majority of the respondents had medium category of Herd size.

\section{Economic motivation}

The data in Table 1 depicts that more than half of the respondents (61.67\%) were found to have medium level of economic motivation followed by high $(33.33 \%)$ and low (5\%) level of economic motivation, respectively in the study sample.

The dairy industry is in continuous loss because of mastitis, high feed cost, exploitation by middleman etc. which leads to decline in earning of farmers. This implies that there exists a tremendous scope to shift the dairy farmers from medium to high economic motivation category provided that the problems mentioned earlier are taken care of properly by the concern agencies. The findings are in line with the findings of Sarita et al., (2016) who found that majority of the respondents were having medium level of economic motivation.

\section{Extension contact}

It can be noticed from the Table 1 that the majority of the respondents $(55.83 \%)$ had medium level of extension contacts, followed by low (22.5\%) and high (21.67\%) level of extension contacts. This in turn shows that various service providers including NGOs, Vety. Functionaries, Dairy Cooperatives Societies (DCSs) etc are in regular touch with dairy farmers and catering the needs to satisfaction level of the farmers. The findings are in line with the findings of Chaurasiya (2015) who found that majority of the respondents were having medium level of extension contact.

\section{Mass media exposure}

It refers to the exposure and use of different mass media for getting information by the respondents. It can be seen from Table 1 that majority 73.34 per cent of the dairy farmers were found in the medium level of mass media exposure category while 23.33 and 3.33 per cent of them were hailed to low and high level of mass media exposure category, respectively. This implies that farmers use the mass media like radio, TV, mobile phone, farm literature etc. for getting information on scientific dairy management, leading to good results pertaining to mass media exposure. It must be noted that still there is a scope to improve the situation by telecasting or broadcasting more programmes for the benefit of livestock owners. The findings are in line with the findings of Chaurasiya (2015) who found that majority of the respondents belongs to medium category of mass media exposure.

It can be concluded from above findings that majority of the respondents were having middle age group, Middle level of education, medium family size and medium dairy experience. It can also observed that majority of the respondents had not attended any training related to dairy management practices. Majority of the respondent were having medium level of economic motivation, extension contact and mass media exposure. Based on the study results it suggested that 
there is a need for conducting need based training programmes by the extension agencies in the study area. Latest information related to dairy management practices should be disseminated through radio and T.V. Farm literature like leaflets, pamphlets and folders etc. may be prepared having impact points of dairy management practices in simple and local language and distributed free of cost to the farmers.

\section{References}

$19^{\text {th }}$ livestock census Rajasthan-2012. http://animalhusbandry.rajasthan.gov.in/ livestock_census.aspx

Anonymous, 2012. Department of animal husbandry, Government of Rajasthan.

Anonymous, 2014.19th Livestock Census 2012. Department of Animal Husbandry, Dairying and Fisheries, Ministry of Agriculture, Government of India, New Delhi.

Bhosale, S.R., Deshmukh, A.N., Godse, S.K. and Shelake, P.S. 2014. Entrepreneurial behaviour of dairy farmers. Advance Research journal of social science 5 (2)171-174

Chandrasekar, G.K., Satyanarayan, K., Jagadeeswary, V. and Shree, J.S. 2017. Relationship between Socio-Economic and Psychological factors of dairy farmers with days open - A study in Rural Karnataka. Indian journal of pure and applied bioscience 5 (1): 171-177

Godara, P.K. 2017. A study on entrepreneurial behaviour of dairy livestock owners in Bikaner District of Rajasthan. M.V.Sc. Thesis submitted to RAJUVAS Bikaner.

Jaiswal, A., Patel, M.M. and Dubey, R. 2013. An analysis of Socio-economic and Psychological attributes of rural women entrepreneur in Indore block of Indore district Madhya Pradesh, India. International Journal of Current Microbiology Applied Sciences 3(1): 582-585

Raina, V., Bhushan., B., Bakshi., P. and Khajuria., S. 2016. Entrepreneurial Behaviour of Dairy Farmers. Journal of Animal Research 6(5): 947-953.

Raval and Chandawat, M.S. 2011.Extent of knowledge of improved animal husbandry practices and socioeconomical characteristics of dairy farmers of district Kheda, Gujarat. International Journal of Farm Sciences, 1(2):129-137.

Roy, M. L., Nirmal Chandra, Kharbikar, H.L. Joshi P. and Jethi R. 2013. Socioeconomic Status of Hill Farmers: An Exploration from Almora District in Uttarakhand. International Journal of Agriculture and Food Science Technology 4 (4): 353-358

Sarita, Singh S.P., Malik, A., Sharma, M., and Ahuja, R. 2016.Socio-Economic and Psychological characteristics of dairy farmers of Hisar district. International journal of science, environment and technology, 5(5):3466 - 3472

\section{How to cite this article:}

Rahul Choudhary, Rohitash Kumar and Vinay Kumar. 2018. Socio-Economic Personal Antecedents of Dairy Farmers of Jaipur District of Rajasthan, India. Int.J.Curr.Microbiol.App.Sci. 7(09): 3471-3476. doi: https://doi.org/10.20546/ijcmas.2018.709.430 